\title{
Hypersensitivity Reactions Associated with Platinum Antineoplastic Agents: A Systematic Review
}

\author{
Nektaria Makrilia, ${ }^{1}$ Ekaterini Syrigou, ${ }^{1}$ Ioannis Kaklamanos, ${ }^{1}$ Leonidas Manolopoulos, ${ }^{1}$ and \\ Muhammad Wasif Saif ${ }^{2}$ \\ ${ }^{1}$ Oncology Unit, 3rd Department of Medicine, Sotiria General Hospital, Athens University School of Medicine, \\ Mesogion 152, 11527 Athens, Greece \\ ${ }^{2}$ Department of Clinical Oncology, Yale University School of Medicine, New Haven, CT 06510, USA
}

Correspondence should be addressed to Nektaria Makrilia, makmacs@hotmail.com

Received 20 May 2010; Accepted 14 July 2010

Academic Editor: Andrea Bonetti

Copyright (C) 2010 Nektaria Makrilia et al. This is an open access article distributed under the Creative Commons Attribution License, which permits unrestricted use, distribution, and reproduction in any medium, provided the original work is properly cited.

\begin{abstract}
Platinum-containing chemotherapy agents (cisplatin, carboplatin, oxaliplatin) have been approved in the first-line setting of numerous malignancies, such as ovarian, bladder, head and neck, colorectal, and lung cancer. Their extensive use over the last decade has led to a significant increase in the incidence of hypersensitivity reactions, which are defined as unforeseen reactions whose signs and symptoms cannot be explained by the known toxicity of these drugs. Skin rash, flushing, abdominal cramping, itchy palms, and back pain are common symptoms. Cardiovascular and respiratory complications can prove fatal. Multiple pathogenetic mechanisms have been suggested. Hypersensitivity usually appears after multiple infusions, suggesting type I allergic reactions; however, other types of hypersensitivity also seem to be implicated. Several management options are available to treating physicians: discontinuation of chemotherapy, premedication, prolonging of infusion duration, desensitization protocols, and replacement with a different platinum compound after performing skin tests that rule out cross-reactions among platinum agents.
\end{abstract}

\section{Introduction}

Platinum-based compounds were first synthesized in the nineteenth century but their clinical use against cancer did not start until the 1970s. Their activity consists of forming DNA addicts that inhibit replication and lead to apoptosis $[1,2]$. They have been approved for the treatment of numerous malignancies, such as ovarian, primary peritoneal carcinoma, bladder, head and neck, colorectal, pancreatic, esophageal, gastric, testicular, endometrial, biliary tract, and lung cancer and mesothelioma [3-15]. Platinum agents are also effective in pediatric tumors $[16,17]$. They are used in the first-line and adjuvant setting but also as retreatment regimens when there is a long progression-free interval after treating with the same drugs $[18,19]$.

Cisplatin [(SP-4-2)-diamminedichloroplatinum] was the first of the platinum drugs to be used and is characterized by neurotoxicity, nephrotoxicity, ototoxicity, and emetogenicity [1]. Second-generation platinum derivative carboplatin [cis-diammine (cyclobutane-1,1-dicarboxylate$O, O^{\prime}$ )platinum(II)] differs from cisplatin in the substitution of two chlorides by a 1,1-cyclobutane dicarboxylate group. Its efficacy in the treatment of many of the above malignancies is equal to that of cisplatin, and its toxicity profile is more favorable [20]. Thus, carboplatin has often been used in place of cisplatin $[21,22]$. Oxaliplatin $[[(1 R, 2 R)$-cyclohexane1,2 -diamine] (ethanedioate- $O, O^{\prime}$ )platinum(II)] is a thirdgeneration platinum compound widely used for the treatment of metastatic colorectal cancer and a variety of other malignancies, such as breast cancer, melanoma, nonHodgkin lymphoma, and head and neck cancer [23-25]. Common adverse events are myelotoxicity, nausea, vomiting diarrhea, paresthesia, and dysesthesias [26-28].

Hypersensitivity to a chemotherapeutic agent is defined as an unforeseen reaction whose signs and symptoms cannot be explained by the known toxicity of the drug [29]. Industrial complex platinum salts have been reported to cause hypersensitivity and asthma among refinery workers since 
1945 [30]. Hypersensitivity reactions in patients receiving cisplatin were first described in the 1970s in patients who had been retreated with the drug [31]. Since then, all platinum agents have been associated with such reactions.

The aim of this paper is to provide recent data concerning hypersensitivity reactions to platinum-containing chemotherapy agents. We will present the characteristics and pathogenetic mechanisms of this hypersensitivity, as well as the basic management options available to date.

\section{Incidence}

Extensive use of platinum compounds in chemotherapy during the last decade has led to a significant increase in the incidence of hypersensitivity reactions (Table 1 ). Hypersensitivity to carboplatin is rarely observed during the first course of treatment. In fact, the most striking difference of carboplatin hypersensitivity, when compared to nonplatinum agents, is the fact that most allergic reactions are reported after the patient has received a significant number of infusions although he has exhibited no hypersensitivity up until then [32-37]. Half of the reactions observed are moderate to severe [32]. During the first five cycles, the overall risk is less than $1 \%$ [38]; it rises sharply to $6.5 \%$ with the sixth cycle [39] and has been reported as high as $27 \%$ in patients receiving more than seven cycles of treatment [32, $40,41]$. The overall incidence of carboplatin hypersensitivity reaches $44 \%$ in the third-line retreatment setting [32, 42]. Reactions to carboplatin are usually observed after a median number of eight infusions [32, 33, 39]. Markman et al. were the first to report that peak incidence of carboplatin reaction is observed during cycle 2 in the second-line setting [32]. The incidence of cisplatin hypersensitivity exhibits similar characteristics to those observed with carboplatin. It seems to range from $5 \%$ to $20 \%$ and increases with concomitant radiation [43]. Oxaliplatin-related hypersensitivity reactions were originally considered less common, but with the growing use of this drug during the last years, it has been found that reactions occur at a frequency as high as $18.9 \%$ $[44,45]$. However, severe grade 3 or 4 events occur in only $1.6 \%$ of patients [46]. These reactions usually develop after six drug infusions [47]. Severe anaphylaxis is rarely observed and is mostly described in case reports $[48,49]$.

To the best of our knowledge, there have still been no reports of hypersensitivity reactions associated with newer platinum compounds (i.e., satraplatin, picoplatin). This, however, may be partly attributed to the fact that for some of the trials conducted, known hypersensitivity to platinumcontaining compounds was an exclusion criterium. The prevalence of hypersensitivity to these agents remains to be explored in larger studies in the future.

\section{Risk Factors}

Factors predictive of hypersensitivity reactions to platinum agents are yet to be clarified. HLA phenotype and intensity of exposure influence the possibility of sensitization in refinery workers [67]. Prior history of allergy to drugs and various
TABLE 1: Incidence and severity of hypersensitivity to platinum agents.

\begin{tabular}{|c|c|c|}
\hline Drug & $\begin{array}{c}\text { Overall } \\
\text { incidence \% }\end{array}$ & Characteristics/Severity \\
\hline \multirow{3}{*}{ Cisplatin } & \multirow{3}{*}{$5-20$} & $\begin{array}{l}\text { (i) Occurs within minutes of } \\
\text { infusion start }\end{array}$ \\
\hline & & $\begin{array}{l}\text { (ii) Mostly between } 4 \text { th-8th } \\
\text { course }\end{array}$ \\
\hline & & $\begin{array}{l}\text { (iii) Increases with concomitant } \\
\text { radiation }\end{array}$ \\
\hline \multirow{6}{*}{ Carboplatin } & \multirow{6}{*}{$1-44$} & $\begin{array}{l}\text { (i) Occurs within minutes or } \\
\text { days from infusion }\end{array}$ \\
\hline & & $\begin{array}{l}\text { (ii) less than } 1 \% \text { during cycles } \\
1-5\end{array}$ \\
\hline & & (iii) $6.5 \%$ in cycle 6 \\
\hline & & (iv) $27 \%$ in cycle 7 or more \\
\hline & & (v) $44 \%$ in 3 rd-line retreatment \\
\hline & & $\begin{array}{l}\text { Half of all reactions observed are } \\
\text { moderate to severe }\end{array}$ \\
\hline \multirow{4}{*}{ Oxaliplatin } & \multirow{4}{*}{$10-18.9$} & $\begin{array}{l}\text { (i) Occurs within minutes/hours } \\
\text { from infusion }\end{array}$ \\
\hline & & (ii) Mostly after 6th course \\
\hline & & (iii) Grade $3-4$ in only $1.6 \%$ \\
\hline & & $\begin{array}{l}\text { (iv) Severe anaphylaxis mostly in } \\
\text { case reports }\end{array}$ \\
\hline
\end{tabular}

environmental factors are associated with greater risk [68, 69].

In patients receiving carboplatin, the number of prior platinum treatments and total lifetime exposure is associated with possibility of hypersensitivity [32, 34, 69-72], but it is not clear whether lowering individual doses during retreatment would reduce the risk [34]. The interval between the last infusion of first-line chemotherapy and retreatment is an independent predictive variable [69]. High rate of drug infusion also seems to be vital [16] whereas selection of first-line and retreatment regimens is not influential [69]. Most recently, Sugimoto et al. showed that patients with carboplatin-free interval $>13$ months was related to a 22 fold higher risk of hypersensitivity and that a maximum dose/body of carboplatin $>650 \mathrm{mg}$ is also an independent risk factor [40]. Navo et al. observed that carboplatin hypersensitivity is more frequent in patients with ovarian cancer [70]. A retrospective study by Lafay-Cousin et al. in pediatric patients with low-grade glioma concluded that hypersensitivity reactions occurred significantly earlier in children receiving weekly carboplatin infusions as compared to children on a monthly schedule. Being a girl was identified as a risk factor. The cumulative risk of allergic reactions increased with the number of infusions, and there was no evidence of a plateau [17]. It has also been found that the eosinophilic number and ratio during the previous cycle of allergy and on the day of an allergic reaction are not helpful in predicting a hypersensitivity response [73].

The incidence of carboplatin hypersensitivity also seems to be associated with the type of antineoplastic drugs it is 
TABle 2: Types of hypersensitivity reactions, their characteristics, and how they are implicated in platinum agent hypersensitivity.

\begin{tabular}{lccccc}
\hline $\begin{array}{l}\text { Type of } \\
\text { hypersensitivity }\end{array}$ & Antigen & Mediated by & Mechanism & $\begin{array}{c}\text { Involved in platinum } \\
\text { hypersensitivity }\end{array}$ & Symptoms related \\
I & Soluble antigen & IgE & $\begin{array}{c}\text { Mast cell and basophil } \\
\text { degranulation }\end{array}$ & $\begin{array}{c}\text { Carboplatin, Cisplatin, } \\
\text { Oxaliplatin (most) }\end{array}$ & $\begin{array}{c}\text { Early onset symptoms: } \\
\text { itching, chest pain, rash, } \\
\text { anaphylactic reactions }\end{array}$ \\
\hline II & $\begin{array}{c}\text { Cell- or matrix- } \\
\text { associated antigen }\end{array}$ & IgG, IgM & $\begin{array}{c}\text { Phagocyte and NK-cell } \\
\text { activation }\end{array}$ & Oxaliplatin & $\begin{array}{c}\text { Hemolysis, } \\
\text { thrombocytopenia }\end{array}$ \\
\hline III & Soluble antigen & IgG & $\begin{array}{c}\text { Immune complexes, } \\
\text { Phagocyte and NK-cell } \\
\text { activation, complement } \\
\text { fixation }\end{array}$ & Oxaliplatin & $\begin{array}{c}\text { Chronic urticaria, joint } \\
\text { pain, proteinuria }\end{array}$ \\
\hline IV & $\begin{array}{c}\text { Soluble or } \\
\text { cell-associated } \\
\text { antigen }\end{array}$ & $\begin{array}{c}\text { T-cells (TH1, TH2, } \\
\text { Cytotoxic T cells) }\end{array}$ & $\begin{array}{c}\text { Macrophage and } \\
\text { eosinophil activation, } \\
\text { cytotoxicity }\end{array}$ & Carboplatin, Cisplatin & $\begin{array}{c}\text { Delayed reactions, hours } \\
\text { or even days after } \\
\text { infusion }\end{array}$ \\
\hline
\end{tabular}

TABLE 3: Emergency procedures in case of hypersensitivity reactions.

Emergency procedures in case of hypersensitivity reaction to a platinum agent

(1) Interruption of infusion

(2) Administer: i.v. antihistamines (type 1 and 2 histamine receptor antagonists), normal saline infusion, and low-dose corticosteroids (antihistamines are the first to be administered)

(3) In case of a more severe reaction (dyspnoea, laryngospasm, bronchospasm):

(i) oxygen, bronchodilators

(ii) high dose steroids (doses range between 100 and $1000 \mathrm{mg}$ of hydrocortisone)

(4) Administer epinephrine in case of hypotension or airway obstruction symptoms

(5) Monitoring until symptoms resolve or for several hours later in case of severe hypersensitivity

combined with. More specifically, the CALYPSO trial showed that hypersensitivity reactions occurred more frequently in patients receiving carboplatin-paclitaxel, as compared to patients on a combination of carboplatin with pegylated liposomal doxorubicin (PLD) (18.8\% versus 5.6\%, resp.) [74]. Markman et al. also reached the conclusion that administering PLD with carboplatin substantially reduces the incidence of carboplatin-associated hypersensitivity [75].

In oxaliplatin regimens, younger age, female sex, and use of this platinum compound as salvage therapy have recently been recognized as potential risk factors [46] as opposed to type and number of metastatic sites [45].

\section{Pathophysiology}

The exact mechanism of platinum allergy remains unclear (Table 2) although multiple studies have tried to explain the underlying pathophysiology. Reactions are thought to be mainly caused by type I IgE-mediated or type IV T-cellmediated hypersensitivity. Nevertheless, the presentation pattern of these reactions is unpredictable, suggesting that various immunological and nonimmunological mechanisms are involved [30].

In type I hypersensitivity reactions, IgE immunoglobulin causes the degranulation of mast cells and basophils leading to the nonimmune-mediated histamine and cytokine release [32, 38, 76, 77]. Early-onset symptoms, such as itching, chest pain, rash, and anaphylactic reactions are attributed to this pathway [32]. Hypersensitivity in exposed refinery workers $[30,39]$, the need of multiple infusions for sensitization, and positive carboplatin skin tests are in favor of the above hypersensitivity mechanism but no study has searched for platinum-specific IgE $[30,78,79]$. Type IV hypersensitivity to platinum agents also seems to be involved. Antigens binding to the major histocompatibility complex activate $\mathrm{T}$ cells that have already been sensitized. This hypersensitivity is associated with the delayed inflammatory reaction presenting hours or even days after the infusion $[32,80]$. Increased production of cytokines, such as tumor necrosis factor (TNF)-alpha and interleukin (IL)-6, might be caused by platinum compounds acting as superantigens, but this has yet to be proven $[80,81]$. According to the latest hypersensitivity models, serotonin is also implicated in anaphylactic mechanisms, and this could explain the symptoms of hypertension and bronchospasm [82].

As far as oxaliplatin is concerned, most reactions seem to be IgE-mediated but type II hypersensitivity is also implicated with the presentation of hemolysis and thrombocytopenia [83]. Chronic urticaria, joint pain, and proteinuria after oxaliplatin regimens have been attributed to type III allergic reactions [73]. Furthermore, idiosyncratic reactions characterized by chills, fever, abdominal cramps, and chest tightness have been described during the infusion $[81,84,85]$.

The development of carboplatin hypersensitivity after a median number of eight therapy courses has been attributed 
TABLE 4: Main desensitization protocols for carboplatin-cisplatin hypersensitivity. We observe that all protocols deliver the platinum agent at escalating concentrations and administer premedication.

\begin{tabular}{|c|c|c|c|c|c|}
\hline & Patients & $\begin{array}{l}\text { Premedication dose } \\
\text { route }\end{array}$ & Steps & Duration & Success rate \\
\hline $\begin{array}{l}\text { Abe et al. } \\
(2010)[50]\end{array}$ & $\begin{array}{c}3 \text { (carboplatin } \\
\text { replaced by cisplatin } \\
\text { after } \\
\text { desensitization) }\end{array}$ & $\begin{array}{c}\text { Dexamethasone } \\
20 \mathrm{mg} \text {, promethazine } \\
50 \mathrm{mg} \text {, ranitidine } \\
50 \mathrm{mg}\end{array}$ & $\begin{array}{l}\text { From } 1: 1000 \text { to } 1: 10 \\
\text { on } 1 \text { st day (in } 3 \text { steps), } \\
\text { from } 1: 10 \text { to } 1: 1 \text { on } \\
2 \text { nd day (in } 2 \text { steps) }\end{array}$ & $\begin{array}{l}2 \text { days ( } 3 \text { hours on } 1 \text { st } \\
\text { day, } 9 \text { hours on } 2 \text { nd day) }\end{array}$ & $100 \%$ \\
\hline $\begin{array}{l}\text { Gomez et al. } \\
(2009)[51]\end{array}$ & 7 & $\begin{array}{l}\text { Dexamethasone at } \\
\text { least } 20 \mathrm{mg} \text { iv } 30 \text {, } \\
\text { clemastine } 2 \mathrm{mg} \text { iv }\end{array}$ & $\begin{array}{l}\text { From } 1: 1000 \text { to } 1: 1 \text { in } \\
4 \text { steps }\end{array}$ & 2 hours & $71 \%$ \\
\hline $\begin{array}{l}\text { Hesterberg } \\
\text { et al. (2009) } \\
{[52]}\end{array}$ & 30 & $\begin{array}{c}\text { Fexofenadine } 180 \mathrm{mg} \\
\text { po and/or } \\
\text { desloratadine } 5 \mathrm{mg} \text { po } \\
\text { BID, Dexamethasone } \\
10 \mathrm{mg} \text { po }\end{array}$ & $\begin{array}{l}\text { From } 1: 100 \text { to } 1: 1 \text { (in } \\
\quad 8-10 \text { steps) }\end{array}$ & 11 hours & $99 \%$ \\
\hline $\begin{array}{l}\text { Castells } \\
\text { et al. (2008) } \\
{[53]}\end{array}$ & $\begin{array}{l}63 \text { ( } 60 \\
\text { hypersensitive to } \\
\text { carboplatin, } 3 \text { to } \\
\text { cisplatin) }\end{array}$ & $\begin{array}{l}\text { Diphenhydramine or } \\
\text { hydroxyzine } 25 \mathrm{mg} \text { po } \\
\text { or iv, famotidine } \\
20 \mathrm{mg} \text { iv or ranitidine } \\
50 \mathrm{mg} \text { iv, lorazepam } \\
(0.5-1 \mathrm{mg} \text { po or iv as } \\
\text { needed for anxiety) }\end{array}$ & $\begin{array}{l}\text { From } 1: 100 \text { to } 1: 1 \text { in } \\
12 \text { steps }\end{array}$ & 5.8 hours & $\begin{array}{l}\text { Severe reactions } \\
\text { in } 6 \% \text { of courses } \\
\text { (full target dose } \\
\text { with treatment) }\end{array}$ \\
\hline $\begin{array}{l}\text { Confino- } \\
\text { Cohen et al. } \\
(2005)[54] \\
\end{array}$ & 23 & $\begin{array}{l}\text { Dexamethasone } \\
8-12 \text { mg iv, } \\
\text { ondansetron iv }\end{array}$ & $\begin{array}{c}\text { From } 1: 1000 \text { to } 1: 1 \text { in } \\
4 \text { steps }\end{array}$ & 6 hours & $86.9 \%$ \\
\hline $\begin{array}{l}\text { Lee et al. } \\
(2005)[55]\end{array}$ & $\begin{array}{c}31 \text { (1st } \\
\text { desensitization in } \\
\text { intensive care } \\
\text { unit—subsequent as } \\
\text { outpatient) }\end{array}$ & $\begin{array}{l}\text { Diphenhydramine } \\
25 \mathrm{mg} \text { iv, famotidine } \\
20 \mathrm{mg} \text { iv Lorazepam } \\
1 \mathrm{mg} \text { (as needed for } \\
\text { anxiety) }\end{array}$ & $\begin{array}{c}\text { From } 1: 100 \text { to } 1: 1 \text { in } \\
12 \text { steps(higher } \\
\text { concentrations as } \\
\text { outpatient) }\end{array}$ & $\begin{array}{l}5.8 \text { hours (inpatient) } 3.8 \\
\text { hours (outpatient) }\end{array}$ & $\begin{array}{c}85 \% \text { courses } \\
\text { without } \\
\text { symptoms (full } \\
\text { target dose with } \\
\text { treatment) }\end{array}$ \\
\hline $\begin{array}{l}\text { Markman } \\
\text { et al. }(2004) \\
{[56]}\end{array}$ & $\begin{array}{c}5 \text { (desensitization } \\
\text { and retreatment } \\
\text { with carboplatin or } \\
\text { cisplatin) }\end{array}$ & $\begin{array}{l}\text { Zileuton } 600 \text { mg po } \\
\text { QID (5 days), } \\
\text { montelukast sodium } \\
10 \text { mg po QD ( } 5 \\
\text { days), indomethacin } \\
50 \mathrm{mg} \text { po TID ( } 1 \text { day), } \\
\text { albuterol sulfate } 8 \mathrm{mg} \\
\text { po BID ( } 1 \text { day), } \\
\text { famotidine } 20 \mathrm{mg} \text { iv, } \\
\text { dexamethasone } 20 \mathrm{mg} \\
\text { iv, diphenhydramine } \\
50 \text { mg iv }\end{array}$ & $\begin{array}{c}\text { From } 1: 1000 \text { to } 1: 1 \text { in } \\
4 \text { steps }\end{array}$ & 90 minutes & $80 \%$ \\
\hline $\begin{array}{l}\text { Jones et al. } \\
(2003) \text { [57] }\end{array}$ & $\begin{array}{c}5 \text { (carboplatin } \\
\text { replaced by cisplatin } \\
\text { after } \\
\text { desensitization) }\end{array}$ & $\begin{array}{c}\text { Dexamethasone } \\
20 \mathrm{mg} \text { po ( } 4 \text { days ), } \\
\text { diphenhydramine } \\
50 \mathrm{mg} \text { po ( } 4 \text { days), } \\
\text { ranitidine } 50 \mathrm{mg} \text { iv, } \\
\text { dexamethasone } 20 \mathrm{mg} \\
\text { iv, ondansetron } 8 \mathrm{mg} \\
\text { iv }\end{array}$ & $\begin{array}{c}\text { From } 1: 1000 \text { to } 1: 1 \text { in } \\
4 \text { steps }\end{array}$ & 2 hours & $60 \%$ \\
\hline $\begin{array}{l}\text { Rose et al. } \\
\text { (2003) [33] }\end{array}$ & 33 & $\begin{array}{c}\text { Dexamethasone } \\
20 \mathrm{mg} \text { po or iv } 6 \text { hours } \\
\text { before, } \\
\text { Dexamethasone } \\
20 \mathrm{mg} \text { iv and } \\
\text { diphenhydramine } \\
50 \mathrm{mg} \text { iv } 30 \text { minutes } \\
\text { before }\end{array}$ & $\begin{array}{c}\text { From } 1: 1000 \text { to } 1: 1 \text { in } \\
4 \text { steps }\end{array}$ & 16.5 hours & $79 \%$ \\
\hline
\end{tabular}

BID: twice a day, iv: intravenously, po: by mouth, QD: once a day, QID: four times a day, TID: three times a day. 
TABLE 5: Castells' 12-step desensitization protocol.

\begin{tabular}{|c|c|c|c|c|}
\hline Step & Solution & $\begin{array}{c}\text { Rate } \\
(\mathrm{mL} / \mathrm{h})\end{array}$ & $\begin{array}{l}\text { Time (in } \\
\text { minutes) }\end{array}$ & $\begin{array}{c}\text { Volume } \\
\text { infused } \\
\text { per step } \\
(\mathrm{mL})\end{array}$ \\
\hline 1 & \multirow{4}{*}{$\begin{array}{l}\text { 100-fold dilution of final } \\
\text { target concentration }\end{array}$} & 2.0 & 15 & 0.50 \\
\hline 2 & & 5.0 & 15 & 1.25 \\
\hline 3 & & 10.0 & 15 & 2.50 \\
\hline 4 & & 20.0 & 15 & 5.00 \\
\hline 5 & \multirow{4}{*}{$\begin{array}{l}10 \text {-fold dilution of final } \\
\text { target concentration }\end{array}$} & 5.0 & 15 & 1.25 \\
\hline 6 & & 10.0 & 15 & 2.50 \\
\hline 7 & & 20.0 & 15 & 5.00 \\
\hline 8 & & 40.0 & 15 & 10.00 \\
\hline 9 & \multirow{4}{*}{$\begin{array}{l}\text { Concentration was } \\
\text { calculated by subtracting } \\
\text { the cumulative dose } \\
\text { administered in steps } 1-8 \\
\text { from the total target dose }\end{array}$} & 10.0 & 15 & 2.50 \\
\hline 10 & & 20.0 & 15 & 5.00 \\
\hline 11 & & 40.0 & 15 & 10.00 \\
\hline 12 & & 75.0 & $\begin{array}{l}\text { prolonged } \\
\text { to } \\
\text { complete } \\
\text { target dose }\end{array}$ & 232.50 \\
\hline
\end{tabular}

to the fact that the patient is exposed to very low concentrations of "free" platinum during each infusion. The threshold for the manifestation of a reaction is considered to be lowered with each treatment $[68,86]$. According to Markman et al., the patient is sensitized during the first-line treatment ( 6 courses), and retreatment with the same drug provides the additional immunological stimulation necessary for a reaction during infusion number 8 [32]. Novel studies have suggested that hypersensitivity to platinum agents is not only caused by their common platinum component but also by their different structures and biological targets. According to molecular analyses, cisplatin, carboplatin, and oxaliplatin affect various genes, many of which regulate cell cycle and signal transduction $[87,88]$.

\section{Symptoms}

Platinum hypersensitivity symptoms may develop acutely during infusion or within minutes, hours, or days after the infusion [32]. A mild rash may be the first manifestation of hypersensitivity, and this will be followed by more severe reactions in $50 \%$ of patients. Symptoms of mild hypersensitivity include skin rash, urticaria, flushing, palmar itching, burning, edema of the face and hands, abdominal cramping and diarrhea, back pain, and pruritus. They usually resolve quickly with antihistamines and steroids. More severe reactions manifest with bronchospasm, tachycardia, hypotension or hypertension, seizures, and chest pain. Systemic anaphylaxis may be life-threatening [30, 32, $34,39,76,89,90]$.

In oxaliplatin-based regimens, dysesthesia with laryngeal spasm may occur during, immediately after, or even hours after the drug administration [86, 91-93]. Respiratory problems may be more severe than initially estimated in many cases, as hypoxemia in oxaliplatin-related reactions is often found with no symptoms of dyspnoea [73].

\section{Treatment Strategies}

It is recommended that treating physicians inform patients receiving platinum agents of the risks of hypersensitivity, especially after multiple infusions. It is important for patients to be alert and appropriately educated, so that symptoms are promptly recognized. Administration of platinum drugs should take place in a medical setting with all necessary equipment, and the staff should be experienced in treating hypersensitivity reactions. When a reaction occurs, the infusion should be immediately stopped, and normal saline, intravenous antihistamines, and low-dose corticosteroids should be administered (Table 3 ). The main dilemma is whether the platinum-based regimen should be completely discontinued in future infusions. When the reaction is lifethreatening, all platinum compounds are usually excluded from future treatment options. In case of mild-to-moderate hypersensitivity reactions, there is a range of management options [34].

6.1. Infusion Rate and Premedication. Lowering of infusion rate and use of premedication with corticosteroids and antagonists of histamine receptors have allowed successful readministration of the platinum agent in some case; however there is great risk of recurrence. Some studies actually suggest that in carboplatin patients who still have not exhibited hypersensitivity after a total of 8 infusions, premedication should be given as precaution, and the administration rate should be significantly decreased in order to lower the future risk [34]. A retrospective study was most recently conducted by O'Ceabhaill et al. and included 777 patients with relapsed ovarian, fallopian tube, or primary peritoneal cancer retreated with carboplatin. The data showed that an incrementally increasing, 3-hour infusion during carboplatin retreatment, along with appropriate premedication, may reduce hypersensitivity reactions, when compared to the standard 30-minute infusion [34].

6.2. Desensitization Protocols. Various desensitization protocols have been successfully implemented in order to readminister the same platinum agent, especially in cases where the patient seems to have been benefited by the drug (Table 4). Protocols are based on gradual reintroduction of small amounts of drug antigen while escalating to the full dose, on prolonged infusion and premedication. Successful desensitization protocols are usually time-consuming [30, 32, 33, 38, 50, 53-57, 89-91]. Prolonged desensitization is probably more tolerable when considering the changes caused in the extracellular fluid drug concentration rate [94]. However, rapid protocols that develop desensitization within 4-8 hours have also been attempted [78]. A recent trial by Castells et al. included 413 cases and reported a 12step intravenous and intraperitoneal rapid desensitization protocol that can be applied in a wide range of chemotherapy agents (Table 5). The population consisted predominantly 
TABle 6: Published desensitization protocols for oxaliplatin hypersensitivity. We observe that almost all protocols deliver the platinum agent at escalating concentrations and administer premedication.

\begin{tabular}{|c|c|c|c|c|c|}
\hline & Patients & Premedication-Dose-Route & Steps & Duration & Success rate \\
\hline $\begin{array}{l}\text { Syrigou et al. } \\
\text { (2009) [58] }\end{array}$ & 3 & None & $\begin{array}{l}\text { From } 1: 100000 \text { to } \\
1: 1 \text { in } 13 \text { steps }\end{array}$ & 8 hours & $100 \%$ \\
\hline $\begin{array}{l}\text { Castells et al. } \\
(2008)[53]\end{array}$ & 1 & $\begin{array}{l}\text { Diphenhydramine or hydroxyzine } \\
25 \mathrm{mg} \text { po or iv, famotidine } 20 \mathrm{mg} \text { iv or } \\
\text { ranitidine } 50 \mathrm{mg} \text { iv, lorazepam } \\
(0.5-1 \mathrm{mg} \text { po or iv as needed for } \\
\text { anxiety) }\end{array}$ & $\begin{array}{l}\text { From } 1: 100 \text { to } 1: 1 \text { in } \\
12 \text { steps }\end{array}$ & 5.8 hours & $100 \%$ \\
\hline $\begin{array}{l}\text { Nozawa et al. } \\
(2008) \text { [59] }\end{array}$ & 1 & $\begin{array}{c}\text { Famotidine } 20 \mathrm{mg} \text { iv QD, } \\
\text { Dexamethasone } 20 \mathrm{mg} \text { iv QD, } \\
\text { diphenhydramine } 50 \mathrm{mg} \text { po QID, } \\
\text { domperidone } 10 \mathrm{mg} \text { po QID, } \\
\text { hydrocortisone } 100 \mathrm{mg} \text { iv QD, } \\
\text { granistron } 3 \mathrm{mg} \text { iv QD }\end{array}$ & $\begin{array}{l}\text { From } 1: 10000 \text { to } 1: 1 \\
\quad \text { in } 5 \text { steps }\end{array}$ & 8 hours & $100 \%$ \\
\hline $\begin{array}{l}\text { Wrzesinski et } \\
\text { al. (2007) } \\
{[60]}\end{array}$ & 1 & $\begin{array}{c}\text { Famotidine } 20 \mathrm{mg} \text { iv BID, } \\
\text { Dexamethasone } 20 \mathrm{mg} \text { iv QD, } \\
\text { diphenhydramine } 50 \mathrm{mg} \text { iv QD, } \\
\text { magnesium sulfate } 1 \mathrm{~g} \text { iv BID, calcium } \\
\text { gluconate } 1 \mathrm{~g} \text { iv BID, ondasetron } 8 \mathrm{mg} \\
\text { iv BID }\end{array}$ & $\begin{array}{l}\text { From } 1: 10000 \text { to } 1: 1 \\
\quad \text { in } 5 \text { steps }\end{array}$ & 6 hours & $100 \%$ \\
\hline $\begin{array}{l}\text { Edmondson } \\
\text { et al. (2007) } \\
{[61]}\end{array}$ & 1 & None & $\begin{array}{l}\text { From } 1: 10000 \text { to } 1: 2 \\
\text { in } 12 \text { steps }\end{array}$ & 205 minutes & $100 \%$ \\
\hline $\begin{array}{l}\text { Herrero et al. } \\
(2006)[62]\end{array}$ & 5 & None & $\begin{array}{l}\text { From } 0.003 \text { to } \\
0.75 \mathrm{mg} / \mathrm{min} \text { in } \\
\text { several steps }\end{array}$ & 5-6 hours & $100 \%$ \\
\hline $\begin{array}{l}\text { Mis et al. } \\
(2005)[63]\end{array}$ & 1 & $\begin{array}{c}\text { Dexamethasone } 20 \mathrm{mg} \text { iv, } \\
\text { prednisolone } 20 \mathrm{mg} \text { po QID, } \\
\text { diphenhydramine } 50 \mathrm{mg} \text { iv, cimetidine } \\
300 \mathrm{mg} \text { iv, magnesium sulfate } 1 \mathrm{~g} \text { iv, } \\
\text { calcium gluconate } 1 \mathrm{~g} \text { iv, ondasetron } \\
8 \mathrm{mg} \text { iv }\end{array}$ & $\begin{array}{l}\text { From } 1: 10000 \text { to } 1: 1 \\
\quad \text { in } 5 \text { steps }\end{array}$ & 8 hours & $100 \%$ \\
\hline $\begin{array}{l}\text { Lim et al. } \\
\text { (2004) [64] }\end{array}$ & 1 & $\begin{array}{l}\text { Diphenhydramine } 50 \mathrm{mg} \text { po QID and } \\
30 \mathrm{mg} \text { iv QD, metoclopramide } 9 \mathrm{mg} \text { iv } \\
\text { QD }\end{array}$ & Continuous fixed rate & 24 hours & $100 \%$ \\
\hline $\begin{array}{l}\text { Gammon et } \\
\text { al. }(2004) \\
{[65]}\end{array}$ & 1 & $\begin{array}{l}\text { Dexamethasone iv, hydrocortisone } \\
100 \mathrm{mg} \text { iv, diphenhydramine iv }\end{array}$ & $\begin{array}{l}\text { From } 1: 10000 \text { to } 1: 1 \\
\quad \text { in } 5 \text { steps }\end{array}$ & 8 hours & $100 \%$ \\
\hline $\begin{array}{l}\text { Schüll et al. } \\
(2001)[66]\end{array}$ & 1 & $\begin{array}{l}\text { Dexamethasone iv (high dose), } \\
\text { antihistamine iv, ondasetron } 8 \mathrm{mg} \text { iv }\end{array}$ & Continuous fixed rate & 48 hours & $100 \%$ \\
\hline
\end{tabular}

BID: twice a day, iv: intravenously, po: by mouth, QD: once a day, QID: four times a day.

of women with ovarian cancer, therefore, its efficacy, and safety remain to be proven in other populations as well [53]. It should be noted that there have also been reports of successful desensitization in children [95]. Risks and benefits of desensitization protocols must be carefully weighed, and patients should be informed of the danger as there is still risk of anaphylaxis, or even death during the platinum rechallenge $[89,90,96]$.

6.3. Substituting with a Different Platinum Agent. Substituting one platinum agent with another without additional desensitization is another management option available in case of hypersensitivity [32, 97-100]. Successful replacement of carboplatin by cisplatin has been demonstrated in women with gynecological malignancies [57, 101] but the true incidence of cross-reactivity between platinum salts is not yet known. The possibility of developing a reaction to the substituting platinum agent may be as high as $25 \%$ [101], and cases of fatal cisplatin reactions after carboplatin hypersensitivity have been reported $[89,102]$.

6.4. Skin Testing. Skin testing has been used in an effort to predict hypersensitivity reactions in patients about to be re-administered platinum salts [30, 103]. Markman et al. reported that skin tests had been positive in six of seven patients who later developed anaphylaxis during carboplatin readministration [103], thus, suggesting that hypersensitivity reactions can be predicted. Zanotti et al. [30] used similar 
skin testing to identify patients at risk and reported a 99\% negative predictive value. It seems that skin tests are positive in more than $80 \%$ of reactive patients and that when they are negative, the risk of hypersensitivity reactions is reduced sevenfold or even eliminated $[30,78]$. Therefore, it has been recommended that skin testing is performed in every patient before administration of the eighth dose.

Skin testing can prove helpful in an effort to rule out cross-reactions when one platinum salt is substituted by another $[100,104,105]$. More specifically, patients testing negative for cross-reaction in skin tests seem to be able to safely continue chemotherapy with a different platinum compound. Platinum-based treatment is safely administered without need of pretreatment, and this can prove useful in patients with contraindications to prolonged corticosteroid exposure [102]. It should be noted that patients with positive skin tests were also more likely to exhibit hypersensitivity reactions during desensitization protocols as compared to patients with negative skin tests [52].

The usefulness of skin testing in everyday clinical setting remains an issue of controversy. It does not seem practical to use it as a routine screening test in all patients retreated. It requires prior experience and use of a control. Furthermore, hypersensitivity reactions might still occur even in case of negative skin tests. However, many experts support that skin testing can be extremely helpful when the expected prevalence of hypersensitivity is high. There is need for larger studies in the future in order to clarify the role of skin testing and to establish proper guidelines.

As far as oxaliplatin hypersensitivity is concerned, pretreatment regimens with corticosteroids, antihistamines, and extension of administration time have been somewhat successful but their reliability has not yet been proven $[63,84,91,106-108]$. Brandi et al. [107] and Sui et al. [109] reintroduced oxaliplatin in patients having received prophylactic Dexamethasone and antihistamines but hypersensitivity recurred in a significant number of patients. Similar data were reported by two Japanese retrospective studies $[45,73]$. Oxaliplatin desensitization protocols have been reported in a very small number of patients $[15$, $56,58-66,110]$ with the total infusion time ranging from 2 to 24 hours (Table 6). Better response rates and longer time-to-progression were observed with chronomodulated $(10 \mathrm{am}-10 \mathrm{pm})$ oxaliplatin infusion [111]. Wrzensinski et al. added magnesium sulfate and calcium gluconate to a previously published protocol and suggested that this may increase the success rate of desensitization [60]. Skin testing for oxaliplatin is $75 \%$ to $80 \%$ accurate according to Meyer et al. [110] and Garufi et al. [112].

\section{Conclusions}

Platinum-induced hypersensitivity reactions are a potentially fatal complication that occurs at a rising incidence rate due to the growing use of these agents in chemotherapy. The clinical symptoms range from a mild rash to severe anaphylaxis, and multiple types of hypersensitivity seem to be implicated. Doctors as well as patients should be appropriately educated to promptly recognize symptoms. In case of severe anaphylactic reactions, platinum-based treatment is usually completely discontinued. In more moderate reactions, patients can be rechallenged with infusion rate reduction and premedication, by following a desensitization protocol or by receiving a different platinum chemotherapy agent. Skin testing can help rule out the possibility of crossreaction between platinum-based compounds rendering continuation of effective platinum-based chemotherapy safe.

\section{Conflict of Interest}

The authors declare no conflict of interests.

\section{References}

[1] E. R. Jamieson and S. J. Lippard, "Structure, recognition, and processing of cisplatin-DNA adducts," Chemical Reviews, vol. 99, no. 9, pp. 2467-2498, 1999.

[2] K. Charalabopoulos, S. Karkabounas, E. Ioachim et al., "Antitumour and toxic effects on Wistar rats of two new platinum complexes," European Journal of Clinical Investigation, vol. 32, no. 2, pp. 129-133, 2002.

[3] A. Covens, M. Carey, P. Bryson, S. Verma, M. Fung Kee Fung, and M. Johnston, "Systematic review of first-line chemotherapy for newly diagnosed postoperative patients with stage II, III, or IV epithelial ovarian cancer," Gynecologic Oncology, vol. 85, no. 1, pp. 71-80, 2002.

[4] E. M. Karapanagiotou, P. G. Boura, G. Papamichalis et al., "Carboplatin-pemetrexed adjuvant chemotherapy in resected Non-small Cell Lung Cancer (NSCLC): a phase II study," Anticancer Research, vol. 29, no. 10, pp. 4297-4301, 2009.

[5] V. Georgoulias, A. Agelidou, K. Syrigos et al., "Secondline treatment with irinotecan plus cisplatin vs cisplatin of patients with advanced non-small-cell lung cancer pretreated with taxanes and gemcitabine: a multicenter randomised phase II study," British Journal of Cancer, vol. 93, no. 7, pp. 763-769, 2005.

[6] V. Georgoulias, A. Ardavanis, X. Tsiafaki et al., "Vinorelbine plus cisplatin versus docetaxel plus gemcitabine in advanced non-small-cell lung cancer: a phase III randomized trial," Journal of Clinical Oncology, vol. 23, no. 13, pp. 2937-2945, 2005.

[7] M. Ignatiadis, D. Mavroudis, M. Veslemes et al., "Sequential versus alternating administration of cisplatin/etoposide and topotecan as first-line treatment in extensive-stage small-cell lung cancer: preliminary results of a phase III trial of the hellenic oncology research group," Clinical Lung Cancer, vol. 7, no. 3, pp. 183-189, 2005.

[8] D. Pectasides, E. Samantas, G. Fountzilas et al., "Combination chemotherapy with cisplatin, etoposide and irinotecan in patients with extensive small-cell lung cancer: a phase II study of the Hellenic Co-operative Oncology Group," Lung Cancer, vol. 58, no. 3, pp. 355-361, 2007.

[9] A. Charpidou, S. Tsagouli, S. Tsimpoukis et al., "Triplet combination of carboplatin, irinotecan, and etoposide in the first-line treatment of extensive small-cell lung cancer: a single-institution phase II study," Anti-Cancer Drugs, vol. 21, no. 6, pp. 651-655, 2010.

[10] N. Katirtzoglou, I. Gkiozos, N. Makrilia et al., "Carboplatin plus pemetrexed as first-line treatment of patients with 
malignant pleural mesothelioma: a phase II study," Clinical Lung Cancer, vol. 11, no. 1, pp. 30-35, 2010.

[11] N. Androulakis, G. Aravantinos, K. Syrigos et al., "Oxaliplatin as first-line treatment in inoperable biliary tract carcinoma: a multicenter phase II study," Oncology, vol. 70, no. 4, pp. 280-284, 2006.

[12] N. Ziras, A. Potamianou, I. Varthalitis et al., "Multicenter phase II study of gemcitabine and oxaliplatin (GEMOX) as second-line chemotherapy in colorectal cancer patients pretreated with 5-fluorouracil plus irinotecan," Oncology, vol. 70, no. 2, pp. 106-114, 2006.

[13] N. Androulakis, K. Syrigos, A. Polyzos et al., "Oxaliplatin for pretreated patients with advanced or metastatic pancreatic cancer: a multicenter phase II study," Cancer Investigation, vol. 23, no. 1, pp. 9-12, 2005.

[14] A. Polyzos, K. Syrigos, J. Stergiou et al., "Phase I trial of weekly docetaxel with a 4-weekly cisplatin administration in patients with advanced gastric carcinoma," Cancer Chemotherapy and Pharmacology, vol. 55, no. 5, pp. 466-470, 2005.

[15] K. N. Syrigos, D. Karachalios, E. M. Karapanagiotou, C. M. Nutting, L. Manolopoulos, and K. J. Harrington, "Head and neck cancer in the elderly: an overview on the treatment modalities," Cancer Treatment Reviews, vol. 35, no. 3, pp. 237-245, 2009.

[16] D. Y. Yu, G. V. H. Dahl, R. S. Shames, and P. G. Fisher, "Weekly dosing of carboplatin increases risk of allergy in children," Journal of Pediatric Hematology/Oncology, vol. 23, no. 6, pp. 349-352, 2001.

[17] L. Lafay-Cousin, L. Sung, A.-S. Carret et al., "Carboplatin hypersensitivity reaction in pediatric patients with lowgrade glioma: a canadian pediatric brain tumor consortium experience," Cancer, vol. 112, no. 4, pp. 892-899, 2008.

[18] M. Markman, A. Kennedy, K. Webster, B. Kulp, G. Peterson, and J. Belinson, "Continued chemosensitivity to cisplatin/carboplatin in ovarian carcinoma despite treatment with multiple prior platinum-based regimens," Gynecologic Oncology, vol. 65, no. 3, pp. 434-436, 1997.

[19] S. Kakolyris, N. Ziras, L. Vamvakas et al., "Gemcitabine plus oxaliplatin combination (GEMOX regimen) in pretreated patients with advanced non-small cell lung cancer (NSCLC): a multicenter phase II study," Lung Cancer, vol. 54, no. 3, pp. 347-352, 2006.

[20] R. F. Ozols, B. N. Bundy, B. E. Greer et al., "Phase III trial of carboplatin and paclitaxel compared with cisplatin and paclitaxel in patients with optimally resected stage III ovarian cancer: a Gynecologic Oncology Group study," Journal of Clinical Oncology, vol. 21, no. 17, pp. 3194-3200, 2003.

[21] K. N. Syrigos, J. Vansteenkiste, P. Parikh et al., "Prognostic and predictive factors in a randomized phase III trial comparing cisplatin-pemetrexed versus cisplatin-gemcitabine in advanced non-small-cell lung cancer," Annals of Oncology, vol. 21, no. 3, pp. 556-561, 2010.

[22] I. Gkiozos, A. Charpidou, and K. Syrigos, "Developments in the treatment of non-small cell lung cancer," Anticancer Research, vol. 27, no. 4 C, pp. 2823-2827, 2007.

[23] J. Souglakos, K. Syrigos, A. Potamianou et al., "Combination of irinotecan (CPT-11) plus oxaliplatin (L-OHP) as first-line treatment in locally advanced or metastatic gastric cancer: a multicentre phase II trial," Annals of Oncology, vol. 15, no. 8, pp. 1204-1209, 2004.
[24] A. T. Dimou, K. N. Syrigos, and M. W. Saif, "Neuroendocrine tumors of the pancreas: what's new," Journal of the Pancreas, vol. 11, no. 2, pp. 135-138, 2010, highlights from the "2010 ASCO Gastrointestinal Cancers Symposium".

[25] A. S. Strimpakos, K. N. Syrigos, and M. W. Saif, "Translational research in pancreatic cancer," Journal of the Pancreas, vol. 11, no. 2, pp. 124-127, 2010, highlights from the "2010 ASCO Gastrointestinal Cancers Symposium".

[26] A. S. Strimpakos, K. N. Syrigos, and M. W. Saif, "Pharmacogenetics in pancreatic cancer. Highlights from the "45th ASCO Annual Meeting". Orlando, FL, USA. May 29 - June 2, 2009," Journal of the Pancreas, vol. 10, no. 4, pp. 357-360, 2009.

[27] A. Strimpakos, M. W. Saif, and K. N. Syrigos, "Pancreatic cancer: from molecular pathogenesis to targeted therapy," Cancer and Metastasis Reviews, vol. 27, no. 3, pp. 495-522, 2008.

[28] K. N. Syrigos, D. Sitara, E. Georgiou, and K. J. Harrington, "Cytotoxic therapy of gastroenteropancreatic (GEP) tumors," Anticancer Research, vol. 22, no. 2 B, pp. 1311-1314, 2002.

[29] E. Syrigou, N. Makrilia, I. Koti, M. W. Saif, and K. N. Syrigos, "Hypersensitivity reactions to antineoplastic agents: an overview," Anti-Cancer Drugs, vol. 20, no. 1, pp. 1-6, 2009.

[30] K. M. Zanotti, L. A. Rybicki, A. W. Kennedy et al., "Carboplatin skin testing: a skin-testing protocol for predicting hypersensitivity to carboplatin chemotherapy," Journal of Clinical Oncology, vol. 19, no. 12, pp. 3126-3129, 2001.

[31] M. B. Callahan, J. A. Lachance, R. L. Stone, J. Kelsey, L. W. Rice, and A. A. Jazaeri, "Use of cisplatin without desensitization after carboplatin hypersensitivity reaction in epithelial ovarian and primary peritoneal cancer," American Journal of Obstetrics and Gynecology, vol. 197, no. 2, pp. 199.e1-199.e5, 2007.

[32] M. Markman, A. Kennedy, K. Webster et al., "Clinical features of hypersensitivity reactions to carboplatin," Journal of Clinical Oncology, vol. 17, no. 4, pp. 1141-1145, 1999.

[33] P. G. Rose, N. Fusco, M. Smrekar, K. Mossbruger, and M. Rodriguez, "Successful administration of carboplatin in patients with clinically documented carboplatin hypersensitivity," Gynecologic Oncology, vol. 89, no. 3, pp. 429-433, 2003.

[34] R. O'Cearbhaill, Q. Zhou, A. Iasonos et al., "The prophylactic conversion to an extended infusion schedule and use of premedication to prevent hypersensitivity reactions in ovarian cancer patients during carboplatin retreatment," Gynecologic Oncology, vol. 116, no. 3, pp. 326-331, 2010.

[35] P. A. Kosmidis, H. P. Kalofonos, C. Christodoulou et al., "Paclitaxel and gemcitabine versus carboplatin and gemcitabine in patients with advanced non-small-cell lung cancer. A phase III study of the Hellenic Cooperative Oncology Group," Annals of Oncology, vol. 19, no. 1, pp. 115-122, 2008.

[36] E. M. Karapanagiotou, A. Charpidou, I. Tzannou et al., "A phase II study of sequential docetaxel and gemcitabine followed by docetaxel and carboplatin as first-line therapy for non-small cell lung cancer," Medical Oncology, vol. 25, no. 3, pp. 303-308, 2008.

[37] V. Georgoulias, A. Ardavanis, A. Agelidou et al., "Docetaxel versus docetaxel plus cisplatin as front-line treatment of patients with advanced non-small-cell lung cancer: a randomized, multicenter phase III trial," Journal of Clinical Oncology, vol. 22, no. 13, pp. 2602-2609, 2004. 
[38] H. Kook, K. M. Kim, S. H. Choi et al., "Life-threatening carboplatin hypersensitivity during conditioning for autologous PBSC transplantation: successful rechallenge after desensitization," Bone Marrow Transplantation, vol. 21, no. 7, pp. 727-729, 1998.

[39] S. Sliesoraitis and P. J. Chikhale, "Carboplatin hypersensitivity," International Journal of Gynecological Cancer, vol. 15, no. 1, pp. 13-18, 2005.

[40] H. Sugimoto, T. Iwamoto, Y. Murashima, T. Tabata, N. Sagawa, and M. Okuda, "Risk factors contributing to the development of carboplatin-related delayed hypersensitivity reactions in Japanese patients with gynecologic cancers," Cancer Chemotherapy and Pharmacology, 2010. In press.

[41] A. V. Hoekstra, J. A. Hurteau, C. V. Kirschner, and G. C. Rodriguez, "The combination of monthly carboplatin and weekly paclitaxel is highly active for the treatment of recurrent ovarian cancer," Gynecologic Oncology, vol. 115, no. 3, pp. 377-381, 2009.

[42] J. S. Morgan, M. Adams, and M. D. Mason, "Hypersensitivity reactions to carboplatin given to patients with relapsed ovarian carcinoma," European Journal of Cancer A, vol. 30, no. 8, pp. 1205-1206, 1994.

[43] C. Koren, R. Yerushalmi, A. Katz, H. Malik, A. Sulkes, and E. Fenig, "Hypersensitivity reaction to cisplatin during chemoradiation therapy for gynecologic malignancy," American Journal of Clinical Oncology, vol. 25, no. 6, pp. 625-626, 2002.

[44] M. A. Bautista, W. T. Stevens, C.-S. Chen, B. R. Curtis, R. H. Aster, and C.-T. Hsueh, "Hypersensitivity reaction and acute immune-mediated thrombocytopenia from oxaliplatin: two case reports and a review of the literature," Journal of Hematology and Oncology, vol. 3, article 12, 2010.

[45] Y. Shibata, H. Ariyama, E. Baba et al., "Oxaliplatin-induced allergic reaction in patients with colorectal cancer in Japan," International Journal of Clinical Oncology, vol. 14, no. 5, pp. 397-401, 2009.

[46] B. H. Kim, T. Bradley, J. Tai, and D. R. Budman, "Hypersensitivity to oxaliplatin: an investigation of incidence and risk factors, and literature review," Oncology, vol. 76, no. 4, pp. 231-238, 2009.

[47] A. A. Shlebak, P. I. Clark, and J. A. Green, "Hypersensitivity and cross-reactivity to cisplatin and analogues," Cancer Chemotherapy and Pharmacology, vol. 35, no. 4, pp. 349-351, 1995.

[48] C. Tournigand, F. Maindrault-Goebel, C. Louvet, A. de Gramont, and M. Krulik, "Severe anaphylactic reactions to oxaliplatin," European Journal of Cancer, vol. 34, no. 8, pp. 1297-1298, 1998.

[49] J. Medioni, M. A. Coulon, J. F. Morere, F. Hennebelle, S. Piperno-Neumann, and J. L. Breau, "Anaphylaxis after oxaliplatin,” Annals of Oncology, vol. 10, no. 5, p. 610, 1999.

[50] A. Abe, H. Ikawa, and S. Ikawa, "Desensitization treatment with cisplatin after carboplatin hypersensitivity reaction in gynecologic cancer," Journal of Medical Investigation, vol. 57, no. 1-2, pp. 163-167, 2010.

[51] R. Gomez, P. Harter, H.-J. Lück et al., "Carboplatin hypersensitivity does introduction of skin test and desensitization reliably predict and avoid the problem? A prospective singlecenter study," International Journal of Gynecological Cancer, vol. 19, no. 7, pp. 1284-1287, 2009.

[52] P. E. Hesterberg, A. Banerji, E. Oren et al., "Risk stratification for desensitization of patients with carboplatin hypersensitivity: clinical presentation and management," Journal of
Allergy and Clinical Immunology, vol. 123, no. 6, pp. 12621267, 2009.

[53] M. C. Castells, N. M. Tennant, D. E. Sloane et al., "Hypersensitivity reactions to chemotherapy: outcomes and safety of rapid desensitization in 413 cases," Journal of Allergy and Clinical Immunology, vol. 122, no. 3, pp. 574-580, 2008.

[54] R. Confino-Cohen, A. Fishman, M. Altaras, and A. Goldberg, "Successful carboplatin desensitization in patients with proven carboplatin allergy," Cancer, vol. 104, no. 3, pp. 640643, 2005.

[55] C.-W. Lee, U. A. Matulonis, and M. C. Castells, "Rapid inpatient/outpatient desensitization for chemotherapy hypersensitivity: standard protocol effective in 57 patients for 255 courses," Gynecologic Oncology, vol. 99, no. 2, pp. 393-399, 2005.

[56] M. Markman, F. Hsieh, K. Zanotti et al., "Initial experience with a novel desensitization strategy for carboplatinassociated hypersensitivity reactions: carboplatinhypersensitivity reactions," Journal of Cancer Research and Clinical Oncology, vol. 130, no. 1, pp. 25-28, 2004.

[57] R. Jones, M. Ryan, and M. Friedlander, "Carboplatin hypersensitivity reactions: re-treatment with cisplatin desensitisation," Gynecologic Oncology, vol. 89, no. 1, pp. 112-115, 2003.

[58] E. I. Syrigou, E. M. Karapanagiotou, C. V. Alamara, P. G. Boura, M. W. Saif, and K. N. Syrigos, "Hypersensitivity reactions to oxaliplatin: a retrospective study and the development of a desensitization protocol," Clinical Colorectal Cancer, vol. 8, no. 2, pp. 106-109, 2009.

[59] H. Nozawa, Y. Muto, and Y. Yamada, "Desensitization to oxaliplatin with two stages of premedication in a patient with metastatic rectal cancer," Clinical Therapeutics, vol. 30, no. 6, pp. 1160-1165, 2008.

[60] S. H. Wrzesinski, M. L. McGurk, C. T. Donovan, T. M. Ferencz, and M. W. Saif, "Successful desensitization to oxaliplatin with incorporation of calcium gluconate and magnesium sulfate," Anti-Cancer Drugs, vol. 18, no. 6, pp. 721-724, 2007.

[61] D. A. Edmondson, B. J. Gruling, A. M. Urmanski, S. J. Wong, and M. B. Levy, "Oxaliplatin hypersensitivity: case report and successful repeat desensitization," American Journal of Therapeutics, vol. 14, no. 1, pp. 116-118, 2007.

[62] T. Herrero, P. Tornero, S. Infante et al., "Diagnosis and management of hypersensitivity reactions caused by oxaliplatin," Journal of Investigational Allergology and Clinical Immunology, vol. 16, no. 5, pp. 327-330, 2006.

[63] L. Mis, N. H. Fernando, H. I. Hurwitz, and M. A. Morse, "Successful desensitization to oxaliplatin," Annals of Pharmacotherapy, vol. 39, no. 5, pp. 966-969, 2005.

[64] K.-H. Lim, M.-J. Huang, H.-C. Lin et al., "Hypersensitivity reactions to oxaliplatin: a case report and the success of a continuous infusional desensitization schedule," Anti-Cancer Drugs, vol. 15, no. 6, pp. 605-607, 2004.

[65] D. Gammon, P. Bhargava, and M. J. McCormick, "Hypersensitivity reactions to oxaliplatin and the application of a desensitization protocol," Oncologist, vol. 9, no. 5, pp. 546549, 2004.

[66] B. Schüll, G. V. Kornek, and W. Scheithauer, "Idiosyncratic reaction after oxaliplatin: circumvention by use of a continuous infusional administration schedule," Annals of Oncology, vol. 12, no. 11, pp. 1653-1654, 2001.

[67] A. J. Newman Taylor, P. Cullinan, P. A. Lympany, J. M. Harris, R. J. Dowdeswell, and R. M. Du Bois, "Interaction of HLA 
phenotype and exposure intensity in sensitization to complex platinum salts," American Journal of Respiratory and Critical Care Medicine, vol. 160, no. 2, pp. 435-438, 1999.

[68] M. Markman, K. Zanotti, B. Kulp, G. Peterson, and M. Markman, "Relationship between a history of systemic allergic reactions and risk of subsequent carboplatin hypersensitivity," Gynecologic Oncology, vol. 89, no. 3, pp. 514-516, 2003.

[69] A. Gadducci, R. Tana, G. Teti, G. Zanca, A. Fanucchi, and A. R. Genazzani, "Analysis of the pattern of hypersensitivity reactions in patients receiving carboplatin retreatment for recurrent ovarian cancer," International Journal of Gynecological Cancer, vol. 18, no. 4, pp. 615-620, 2008.

[70] M. Navo, A. Kunthur, M. L. Badell et al., "Evaluation of the incidence of carboplatin hypersensitivity reactions in cancer patients," Gynecologic Oncology, vol. 103, no. 2, pp. 608-613, 2006.

[71] J. R. Schwartz, C. Bandera, A. Bradley et al., "Does the platinum-free interval predict the incidence or severity of hypersensitivity reactions to carboplatin? The experience from Women and Infants' Hospital," Gynecologic Oncology, vol. 105, no. 1, pp. 81-83, 2007.

[72] A. Bamias, K. Syrigos, G. Fountzilas et al., "Intensified bimonthly cisplatin with bolus 5-fluorouracil, continuous 5fluorouracil and high-dose leucovorin (LV5FU2) in patients with advanced gastrointestinal carcinomas: a phase I dosefinding and pharmacokinetic study," American Journal of Clinical Oncology, vol. 27, no. 5, pp. 465-471, 2004.

[73] Y. Ichikawa, A. Goto, S. Hirokawa et al., "Allergic reactions to oxaliplatin in a single Institute in Japan," Japanese Journal of Clinical Oncology, vol. 39, no. 9, pp. 616-620, 2009.

[74] E. Pujade-Lauraine, U. Wagner, E. Aavall-Lundqvist et al., "Pegylated liposomal Doxorubicin and Carboplatin compared with Paclitaxel and Carboplatin for patients with platinum-sensitive ovarian cancer in late relapse," Journal of Clinical Oncology, vol. 28, no. 20, pp. 3323-3329, 2010.

[75] M. Markman, J. Moon, S. Wilczynski et al., "Single agent carboplatin versus carboplatin plus pegylated liposomal doxorubicin in recurrent ovarian cancer: final survival results of a SWOG (S0200) phase 3 randomized trial," Gynecologic Oncology, vol. 116, no. 3, pp. 323-325, 2010.

[76] G. M. Shepherd, "Hypersensitivity reactions to chemotherapeutic drugs," Clinical Reviews in Allergy and Immunology, vol. 24, no. 3, pp. 253-262, 2003.

[77] E. Syrigou, K. Syrigos, and M. W. Saif, "Hypersensitivity reactions to oxaliplatin and other antineoplastic agents," Current Allergy and Asthma Reports, vol. 8, no. 1, pp. 56-62, 2008.

[78] A. Goldberg, R. Confino-Cohen, A. Fishman, Y. Beyth, and M. Altaras, "A modified, prolonged desensitization protocol in carboplatin allergy," Journal of Allergy and Clinical Immunology, vol. 98, no. 4, pp. 841-843, 1996.

[79] E. Enrique, T. Malek, J. V. Castelló, and J. A. de Mateo, "Usefulness of skin testing with platinum salts to demonstrate lack of cross-reactivity between carboplatin and cisplatin," Annals of Allergy, Asthma and Immunology, vol. 100, no. 1, p. 86, 2008.

[80] O. Cromwell, J. Pepys, W. E. Parish, and E. G. Hughes, "Specific IgE antibodies to platinum salts in sensitized workers," Clinical Allergy, vol. 9, no. 2, pp. 109-117, 1979.

[81] D. Santini, G. Tonini, A. Salerno et al., "Idiosyncratic reaction after oxaliplatin infusion," Annals of Oncology, vol. 12, no. 1, pp. 132-133, 2001.
[82] M.-Y. Lee, M.-H. Yang, J.-H. Liu et al., "Severe anaphylactic reactions in patients receiving oxaliplatin therapy: a rare but potentially fatal complication," Supportive Care in Cancer, vol. 15, no. 1, pp. 89-93, 2007.

[83] C. Garufi, S. Vaglio, S. Brienza et al., "Immunohemolytic anemia following oxaliplatin administration," Annals of Oncology, vol. 11, no. 4, p. 497, 2000.

[84] R. R. Thomas, M. G. Quinn, B. Schuler, and J. L. Grem, "Hypersensitivity and idiosyncratic reactions to oxaliplatin," Cancer, vol. 97, no. 9, pp. 2301-2307, 2003.

[85] R. S. de Vries, E. J. Mattijssen, and A. A. van Sorge, "Serious delayed hypersensitivity reaction to oxaliplatin," Annals of Oncology, vol. 17, no. 11, pp. 1723-1724, 2006.

[86] M. Morgan, D. C. Bowers, R. S. Gruchalla, and D. A. Khan, "Safety and efficacy of repeated monthly carboplatin desensitization," Journal of Allergy and Clinical Immunology, vol. 114, no. 4, pp. 974-975, 2004.

[87] A. Vekris, D. Meynard, M.-C. Haaz, M. Bayssas, J. Bonnet, and J. Robert, "Molecular determinants of the cytotoxicity of platinum compounds: the contribution of in silico research," Cancer Research, vol. 64, no. 1, pp. 356-362, 2004.

[88] D. P. Greene, J. S. Ferriss, and A. A. Jazaeri, "Cisplatin administration following carboplatin desensitization failure in primary peritoneal cancer: a brief report," Cancer Chemotherapy and Pharmacology, vol. 66, no. 2, pp. 265-267, 2010.

[89] D. S. Dizon, P. J. Sabbatini, C. Aghajanian, M. L. Hensley, and D. R. Spriggs, "Analysis of patients with epithelial ovarian cancer or fallopian tube carcinoma retreated with cisplatin after the development of a carboplatin allergy," Gynecologic Oncology, vol. 84, no. 3, pp. 378-382, 2002.

[90] S. Zweizig, L. D. Roman, and L. I. Muderspach, "Death from anaphylaxis to cisplatin: a case report," Gynecologic Oncology, vol. 53, no. 1, pp. 121-122, 1994.

[91] F. Maindrault-Goebel, T. André, C. Tournigand et al., "Allergic-type reactions to oxaliplatin: retrospective analysis of 42 patients," European Journal of Cancer, vol. 41, no. 15, pp. 2262-2267, 2005.

[92] S. Potenza, G. Nasti, O. Alessandro, A. Filippelli, F. Rossi, and A. Capuano, "Severe respiratory symptoms to oxaliplatin infusion: a case report of delayed hypersensitivity reaction," Investigational New Drugs, vol. 28, no. 2, pp. 185-186, 2010.

[93] M. W. Saif, S. Roy, L. Ledbetter, J. Madison, and K. Syrigos, "Fever as the only manifestation of hypersensitivity reactions associated with oxaliplatin in a patient with colorectal cancer Oxaliplatin-induced hypersensitivity reaction," World Journal of Gastroenterology, vol. 13, no. 39, pp. 5277-5281, 2007.

[94] M. W. Saif, K. I. Syrigos, S. Hotchkiss et al., "Successful desensitization with cetuximab after an infusion reaction to panitumumab in patients with metastatic colorectal cancer," Cancer Chemotherapy and Pharmacology, vol. 65, no. 1, pp. 107-112, 2009.

[95] J. M. Montiel Herrera, M. A. Góngora-Melendez, M. L. Pineda-Maldonado et al., "Carboplatin hypersensitivity and desensitization in an infant," Therapeutic Drug Monitoring, vol. 32, no. 4, pp. 525-528, 2010.

[96] M. Markman, "Hypersensitivity reactions to carboplatin," Gynecologic Oncology, vol. 84, no. 2, pp. 353-354, 2002.

[97] A. Polyzos, N. Tsavaris, C. Kosmas et al., "Hypersensitivity reactions to carboplatin administration are common but not always severe: a 10-year experience," Oncology, vol. 61, no. 2, pp. 129-133, 2001. 
[98] G. Porzio, P. Marchetti, I. Paris, F. Narducci, E. Ricevuto, and C. Ficorella, "Hypersensitivity reaction to carboplatin: successful resolution by replacement with cisplatin," European Journal of Gynaecological Oncology, vol. 23, no. 4, pp. 335336, 2002.

[99] M. J. Kandel, A. Loehr, P. Harter, A. Traut, K. Gnauert, and A. Du Bois, "Cisplatinum rechallenge in relapsed ovarian cancer patients with platinum reinduction therapy and carboplatin hypersensitivity," International Journal of Gynecological Cancer, vol. 15, no. 5, pp. 780-784, 2005.

[100] K. T. Elligers, M. Davies, D. Sanchis, T. Ferencz, and M. W. Saif, "Rechallenge with cisplatin in a patient with pancreatic cancer who developed a hypersensitivity reaction to oxaliplatin. Is skin test useful in this setting?" Journal of the Pancreas, vol. 9, no. 2, pp. 197-202, 2008.

[101] A. Ottaiano, R. Tambaro, S. Greggi et al., "Safety of cisplatin after severe hypersensitivity reactions to carboplatin in patients with recurrent ovarian carcinoma," Anticancer Research, vol. 23, no. 4, pp. 3465-3468, 2003.

[102] J. B. Robinson, D. Singh, D. C. Bodurka-Bevers, J. T. Wharton, D. M. Gershenson, and J. K. Wolf, "Hypersensitivity reactions and the utility of oral and intravenous desensitization in patients with gynecologic malignancies," Gynecologic Oncology, vol. 82, no. 3, pp. 550-558, 2001.

[103] M. Markman, K. Zanotti, G. Peterson, B. Kulp, K. Webster, and J. Belinson, "Expanded experience with an intradermal skin test to predict for the presence or absence of carboplatin hypersensitivity," Journal of Clinical Oncology, vol. 21, no. 24, pp. 4611-4614, 2003.

[104] V. Leguy-Seguin, G. Jolimoy, B. Coudert et al., "Diagnostic and predictive value of skin testing in platinum salt hypersensitivity," Journal of Allergy and Clinical Immunology, vol. 119, no. 3, pp. 726-730, 2007.

[105] E. Syrigou, N. Makrilia, A. Vassias et al., "Administration of cisplatin in three patients with carboplatin hypersensitivity: is skin testing useful?" Anti-Cancer Drugs, vol. 21, no. 3, pp. 333-338, 2010.

[106] A. Gowda, R. Goel, J. Berdzik, C. G. Leichman, and M. Javle, "Hypersensitivity reactions to oxaliplatin: incidence and management," Oncology, vol. 18, no. 13, pp. 1671-1675, 2004.

[107] G. Brandi, M. A. Pantaleo, C. Galli et al., "Hypersensitivity reactions related to oxaliplatin (OHP)," British Journal of Cancer, vol. 89, no. 3, pp. 477-481, 2003.

[108] P. Bhargava, D. Gammon, and M. J. McCormick, "Hypersensitivity and idiosyncratic reactions to oxaliplatin," Cancer, vol. 100, no. 1, pp. 211-212, 2004.

[109] S. W. K. Siu, R. T. T. Chan, and G. K. H. Au, "Hypersensitivity reactions to oxaliplatin: experience in a single institute," Annals of Oncology, vol. 17, no. 2, pp. 259-261, 2006.

[110] L. Meyer, T. Zuberbier, M. Worm, H. Oettle, and H. Riess, "Hypersensitivity reactions to oxaliplatin: cross-reactivity to carboplatin and the introduction of a desensitization schedule," Journal of Clinical Oncology, vol. 20, no. 4, pp. 1146-1147, 2002.

[111] F. Lévi, R. Zidani, and J.-L. Misset, "Randomised multicentre trial of chronotherapy with oxaliplatin, fluorouracil, and folinic acid in metastatic colorectal cancer," Lancet, vol. 350, no. 9079, pp. 681-686, 1997.

[112] C. Garufi, A. Cristaudo, B. Vanni et al., "Skin testing and hypersensitivity reactions to oxaliplatin," Annals of Oncology, vol. 14, no. 3, pp. 497-498, 2003. 